\title{
HUBUNGAN ANTARA BELAJAR MANDIRI DAN MOTIVASI BERPRESTASI DENGAN HASIL BELAJAR PENDIDIKAN AGAMA ISLAM DI SMP TERBUKA
}

\author{
Nurdin Ibrahim \\ Teknologi Pendidikan FIP UNJ, Jl. Rawamangun Muka Jakarta Timur \\ E-mail nurdin1349@yahoo.com
}

\begin{abstract}
Abstrak
Penelitian ini bertujuan untuk mencari hubungan antara belajar mandiri dan motivasi berprestasi dengan hasil belajar pendidikan agama Islam. Penelitian ini dilaksanakan di SMP Terbuka, yang berinduk di SMP Negeri 55 Tanjung Priok, Jakarta Utara. Penelitian ini menggunakan metode survei pendekatan statistik dengan uji korelasi. Masalah yang menjadi fokus penelitian adalah (1) apakah terdapat hubungan positif antara belajar mandiri $\left(\mathrm{X}_{1}\right)$ dengan hasil belajar pendidikan agama Islam (Y)? (2) apakah terdapat hubungan positif antara motivasi berprestasi $\left(\mathrm{X}_{2}\right)$ dengan hasil belajar pendidikan agama Islam $(\mathrm{Y})$ ? (3) apakah terdapat hubungan positif antara belajar mandiri $\left(X_{1}\right)$ dan motivasi berprestasi $\left(X_{2}\right)$ secara bersama-sama dengan hasil belajar pendidikan agama Islam $(Y)$ ?. Hasil penelitian menunjukkan bahwa 1) terdapat hubungan positif antara belajar mandiri $\left(X_{1}\right)$ dengan hasil belajar pendidikan agama Islam $\left(X_{1}\right.$ dan $\left.\left.Y=0.685\right) .2\right)$ Terdapat hubungan positif antara motivasi berprestasi $\left(X_{2}\right)$ dengan hasil belajar pendidikan agama Islam $\left(X_{2}\right.$ dan $\left.Y=0,631\right)$, dan 3$)$ Terdapat hubungan positif antara belajar mandiri $\left(X_{1}\right)$ dan motivasi berprestasi $\left(X_{2}\right)$ secara bersama-sama dengan hasil belajar pendidikan agama Islam $(X 1$ dan $X 2$ dengan $Y=0,734)$.
\end{abstract}

\begin{abstract}
:
The objective this research was to find the correlation between independent study and achievement motivation and learning outcomes of Islamic religion education. The research was conducted at SMP Terbuka, which affiliated to SMP Negeri 55 of Tanjung Priok in North Jakarta as a Mother School. The method used in this research was survey, statistical approach with correlation test. The problem statements were (1) is there any positive correlation between independent study $\left(\mathrm{X}_{1}\right)$ and learning outcomes of Islamic religion education $(\mathrm{Y})$ ? (2) Is there any positive correlation between achievement motivation $\left(\mathrm{X}_{2}\right)$ and learning outcomes of Islamic religion education (Y)? (3) Is there any positive correlation between independent study $\left(\mathrm{X}_{1}\right)$ and achievement motivation $\left(\mathrm{X}_{2}\right)$ simultaneously with learning outcomes of Islamic religion education $(Y)$ ? The research result showed that 1) There is positive correlation between independent study $\left(X_{1}\right)$ and the Islamic education learning result $\left(X_{1}\right.$ with $\left.\left.Y=0.685\right), 2\right)$. There is positive correlation achievement motivation $\left(\mathrm{X}_{2}\right)$ ) and the learning outcomes of Islamic religion education $\left(\mathrm{X}_{2}\right.$ with $\left.\mathrm{Y}=0.631\right)$ and 3$)$. There is positive correlation between independent study $\left(X_{1}\right)$ and achievement motivation $\left(X_{2}\right)$ simultaneously with the learning outcomes of Islamic religion education $\left(X_{1}\right.$ and $X_{2}$ with $Y=$ $0.734)$.
\end{abstract}

Kata Kunci:

Belajar mandiri, motivasi berprestasi, hasil belajar, pendidikan agama Islam. 
SMP Terbuka merupakan salah satu model layanan pendidikan alternatif jalur sekolah tingkat SMP yang berinduk di SMP Negeri (reguler). SMP Terbuka bukanlah lembaga atau UPT baru yang berdiri sendiri, melainkan menginduk pada SMP reguler yang telah ada. SMP reguler yang menjadi induk menyelenggarakan pendidikan dengan modus dual system (sistem ganda), artinya sekaligus melayani dua kelompok siswa yang berbeda dengan cara belajar yang berbeda. SMP penyelenggara SMP Terbuka pada dasarnya perluasan atau penambahan peran, berupa layanan pendidikan dengan sistem terbuka jarak jauh yang diperuntukkan bagi siswa yang memiliki kendala tertentu, seperti kendala geografis, demografis, sosial, dan ekonomi. Sebagai suatu sistem pendidikan terbuka jarak jauh, SMP Terbuka menerapkan sistem belajar mandiri (independent/individual learning) selama 4-5 hari perminggu dan belajar melalui tatap muka (face to face tutorials) 1-2 hari perminggu. ${ }^{1}$ Belajar mandiri sangat menentukan keberhasilan siswa dalam menyelesaikan modul permbelajaran yang telah dibagikan ke setiap siswa, termasuk modul Pendidikan Agama Islam (PAI).

Menurut Wedermeyer 1973:73 sebagaimana dikutip oleh Keegan, mendefinisikan belajar mandiri sebagai berikut;

Independent learning is that learning, that changed behaviour, that results from aktivities carried on by learner in space and time, learners whose environment is different from that of the school, learners who may be guided by teachers, but who are not dependent upon them, learners who accept degrees of freedom and responsibility in initialing and carrying out the activities that lead to learning. ${ }^{2}$

Dari kutipan di atas, yang disebut belajar mandiri adalah belajar yang mengubah hasil prilaku dari kegiatan yang dilakukan oleh siswa dalam waktu, tempat, dan lingkungan belajar yang berbeda dengan sekolah, siswa dibimbing oleh guru tetapi tidak tergantung (sepenuhnya) kepada mereka, siswa memperoleh kebebasan dan tanggung jawab dalam mengatur dan melaksanakan kegiatan-kegiatan belajar. Dalam belajar mandiri, siswa mempunyai kebebasan untuk belajar tanpa harus menghadiri pelajaran yang diberikan guru. Siswa dapat mempelajari pokok bahasan atau topik pelajaran tertentu dengan membaca modul cetak, buku atau melihat dan mendengarkan program media pembelajaran tanpa bantuan atau dengan bantuan terbatas dari orang lain.

Sejalan dengan Keegan, Moore mengutip pendapat Wedermeyer (1971, p. 550), bahwa:

Independent study consists of various foms of teaching learning in which teachers and learners carry out the essential tasks and responsibilities apart from one another, communicating in a variety of ways for the purpose of freeing internal learners from inappropriate class pacings of patterns, of providing external learners with opportunities to continue learning in their own environments, and of developing in all learners capacity to carry on seif-directed learning 3

Belajar mandiri mengandung berbagai bentuk pembelajaran dimana guru dan siswa melaksanakan tugas-tugas dan tanggung jawab yang esensial berbeda satu dengan yang lain, mengkomunikasikan dalam berbagai cara untuk tujuan memberi- 
kan kebebasan bagi siswa internal (on campus) dari pola kecepatan kelas yang tidak sesuai (dengan dirinya), memberikan kesempatan kepada siswa eksternal untuk melanjutkan belajar dalam lingkungannya sendiri, dan mengembangkan kemampuan seluruh siswa untuk melanjutkan belajar arah diri (belajar sesuai dengan tujuan dan kebutuhan diri siswa). Dari kutipan ini jelas bahwa belajar mandiri tidak hanya berlaku pada pendidikan reguler (siswa on campus) yang tidak mampu mengikuti kecepatan belajar yang telah ditetapkan oleh institusi, namun juga bagi siswa di luar kampus yang bisa belajar di lingkungannya sendiri sesuai dengan kecepatan dan kapasitas (waktu, tempat, dan kemampuan) yang dimilikinya.

Sementara itu, Dabbagh mengutip pendapat Hanson, et al., 1997, p. 9 bahwa, "independent study... the program is more responsive to student needs and goals, and the student accepts a high degree of responsibility for the conduct of the learning programs". ${ }^{4}$ Ini berarti belajar mandiri merupakan suatu program yang lebih responsif terhadap tujuan dan kebutuhan siswa dan siswa memperoleh tanggung jawab yang tinggi untuk melaksanakan program belajarnya.

Di samping itu siswa mempunyai otonomi dalam belajar. Otonomi terwujud dalam beberapa kebebasan, yaitu:

(1) Siswa mempunyai kesempatan untuk ikut menentukan tujuan pembelajaran yang ingin dicapai sesuai dengan kondisi dan kebutuhan belajarnya. (2) Siswa boleh ikut menentukan bahan belajar yang ingin dipelajarinya dan cara mempelajarinya. (3) Siswa mempunyai kebebasan untuk belajar sesuai dengan kecepatannya sendiri. (4) Siswa dapat ikut menentukan cara evaluasi yang akan digunakan untuk menilai kemajuan belajarnya. ${ }^{5}$

Kemandirian dalam belajar perlu diberikan kepada siswa supaya mereka mempunyai tanggung jawab dalam mengatur dan mendisiplinkan dirinya dan dapat mengembangkan kemampuan belajar atas kemauan sendiri. Sikap tersebut perlu dimiliki siswa karena hal tersebut merupakan ciri kedewasaan orang terpelajar. Suatu proses belajar mandiri ialah kesempatan yang diberikan kepada siswa untuk ikut menentukan tujuan, bahan, sumber, dan evaluasi belajarnya. Karena itu program pembelajaran mandiri dapat diklasifikasikan berdasarkan besar kecilnya kebebasan yang diberikan kepada siswa untuk ikut menentukan program pembelajarannya. Tingkat kemandirian siswa dalam belajar dapat diklasifikasi atas:

(1) Otonomi dalam menentukan tujuan pembelajaran yang akan dicapai. Tujuan pembelajaran itu ditentukan oleh siswa, oleh guru atau oleh guru dan siswa. Makin besar kesempatan yang diberikan kepada siswa untuk ikut menentukan tujuan pembelajaran, berarti makin besar kesempatan siswa untuk belajar sesuai dengan kebutuhan belajarnya. (2) Otonomi dalam belajar. Siapakah yang menentukan buku atau media yang akan dipakai dalam belajar? Apakah semuanya ditentukan oleh guru, oleh siswa, atau oleh guru dan siswa? Kalau siswa dapat ikut menentukan bahan belajar. media belajar, dan cara belajar yang akan digunakan untuk mencapai tujuan itu, berarti siswa telah diberi kesempatan untuk bersikap mandiri. (3) Otonomi dalam evaluasi hasil belajar. Siapakah yang menentukan cara dan kriteria evaluasi hasil belajar? Dapatkah siswa pelatihan 
ikut menentukan cara evaluasi dan kriteria penilaian yang akan dipakai? (4) Tingkat kemandirian yang diberikan kepada siswa dalam berbagai program pembelajaran tidak sama. ${ }^{6}$

Belajar mandiri bukan merupakan usaha untuk mengasingkan siswa dari teman belajarnya dan dari guru. Hal yang terpenting dalam proses belajar mandiri ialah peningkatan kemampuan dan keterampilan siswa dalam proses belajar tanpa bantuan orang lain, sehingga pada akhirnya siswa tidak tergantung pada guru, pembimbing, teman atau orang lain dalam belajar. Dalam belajar mandiri siswa akan berusaha sendiri dahulu untuk memahami isi pelajaran yang dibaca, dipelajari atau dilihatnya melalui berbagai sumber dan media pembelajaran. Bila mendapat kesulitan barulah siswa bertanya atau mendiskusikannya dengan teman, guru, atau orang lain. Tugas guru dalam proses belajar mandiri menjadi fasilitator, menjadi orang yang siap memberikan bantuan bila diperlukan (disebut face to face tutorial), terutama bantuan dalam menentukan tujuan belajar, memilih bahan dan media belajar, dan dalam memecahkan kesulitan yang tidak dapat dipecahkan siswa sendiri.

Keberhasilan belajar siswa dalam belajar mandiri, baik pada pendidikan reguler maupun pada system pendidikan terbuka seperti SMP Terbuka, sangat ditentukan oleh motivasi belajar atau motivasi berprestasi dalam belajar. Lebih-lebih dalam belajar mandiri maupun belajar kelompok dengan bantuan terbatas dari guru mata pelajaran.

Secara harfiah, motivasi (Motivation) berasal dari bahasa latin "movere" yang berarti to move atau menggerakkan.7 Sedangkan Suriasumantri berpendapat bahwa motivasi merupakan dorongan, hasrat, atau kebutuhan seseorang. ${ }^{8}$

Motif dan motivasi berkaitan erat dengan penghayatan suatu kebutuhan berperilaku tertentu untuk memenuhi kebutuhan dan pencapaian tujuan yang memenuhi kebutuhan itu. Motif mempunyai pengertian yang sama dengan drive. Drive menghasilkan mobilisasi energi (semangat) dan menguatkan perilaku seseorang. Stimuli drive diasosiasikan dengan drive yang mengarahkan perilaku manusia ke level yang lebih tinggi.

Menurut Beck, et al, ${ }^{9}$ berdasarkan pendekatan regulatoris, "drive sama seperti sebuah kendaraan yang mempunyai suatu mekanisme untuk membawa dan mengarahkan perilaku seseorang. Kegiatan adaptif individu secara biologis mengandung urutan sebagai berikut: Kebutuhan Internal $\rightarrow$ Drive $\rightarrow$ Aktivitas $\rightarrow$ Tujuan $\rightarrow$ Pasif".

Sementara itu, Davies ${ }^{10}$ mengatakan bahwa, motivasi mempunyai empat pengaruh penting dalam pembelajaran, yang tiga di antaranya adalah (a) motivasi memberi semangat siswa, siswa menjadi aktif, sibuk, dan tertarik, motivasi menopang upaya-upaya dan menjaga (belajar) siswa tetap jalan, (b) motivasi mengarahkan dan mengendalikan tujuan, siswa mengarah untuk melengkapi suatu tugas, mencapai tujuan (khusus) yang diinginkan, (c) motivati adalah selektif; siswa dapat menentukan kegiatan apa yang akan dilakukan dan bagaimana tugas-tugas itu akan dilakukan. Dengan demikian, motivasi berfungsi sebagai penentu prioritas untuk keberhasilan seseorang termasuk keberhasilan dalam belajar. Berarti motivasi (berprestasi) mendo- 
rong atau memberi semangat siswa menjadi aktif, sibuk, dan tertarik mempelajari dan membaca berbagai sumber belajar baik secara mandiri maupun kelompok untuk meningkatkan prestasi belajar termasuk hasil belajar Pendidikan Agama Islam (PAI).

Berdasarkan teori atribusi, Crow, Kominsky, dan Padell11 mengatakan bahwa; "penyebab keberhasilan dan kegagalan individu diatribusikan oleh kemampuan, upaya (usaha), kesulitan tugas, dan keberuntungan. Keberhasilan dan kegagalan seseorang dipengaruhi oleh motivasi mereka". Good dan Brophy,12 berpendapat bahwa salah satu dimensi dari teori Atribusi (keberhasilan) adalah locus of causality yang membedakan antara penyebab yang ada dalam diri seseorang (internal), seperti kemampuan (intelegensi) dan upaya, dan penyebab yang ada di luar seseorang (eksternal) seperti tugas yang sulit dan faktor keberuntungan.

Kemampuan dan usaha termasuk dalam dimensi intrinsik, sedangkan sulit atau tidaknya tugas dan faktor keberuntungan termasuk dalam dimensi ektrinsik. Kalau demikian, keempat faktor penyebab kesuksesan dan kegagalan seseorang di atas merupakan indikator atau sub indikator dari motivasi berprestasi.

Sejalan dengan itu, berdasarkan teori Atribusi Weiner dalam Gredler, ${ }^{13}$ ada dua lokus penyebab seseorang berhasil atau berprestasi. Lokus penyebab instrinsik mencakup (1) kemampuan, dan (2) usaha. Lokus penyebab ekstrinsik meliputi (1) kesulitan tugas, (2) nasib baik (keberuntungan), dan (3) faktor lain-lain.

Mc Clleland mengatakan, ${ }^{14}$ motivasi berprestasi mengandung dua aspek, yaitu (1) mencirikan ketahanan dan suatu ketakutan akan kegagalan dan (2) meningkatkan usaha keras yang berguna dan mengharapkan akan keberhasilan. Namun, Travers ${ }^{15}$ berpendapat bahwa ada dua kategori penting dalam motivasi berprestasi, yaitu mengharapkan akan sukses dan takut akan kegagalan. Selanjutnya, dikatakan seseorang menjadi sukses atau gagal, bila dimotivasi oleh kebutuhan untuk berprestasi.

Steers, dan Porter, 16 mengidentifikasi karakteristik orang yang berkebutuhan berprestasi tinggi, yaitu mereka berhasrat kuat memikul tanggung jawab untuk melakukan suatu tugas atau menemukan pemecahan suatu masalah, cenderung bekerja sendiri, bila bekerja kelompok mereka cenderung memilih teman kelompok didasarkan kemampuan daripada temanan; cenderung memilih tujuan-tujuan yang tingkat kesulitannya moderat, mempunyai keinginan untuk memperoleh balikan (feed-back) kinerjanya. Mereka ingin mengetahui hasil pekerjaannya tanpa menghiraukan apakah berhasil atau gagal.

Dari uraian di atas menunjukkan bahwa setidak-tidaknya ada dua indikator dalam motivasi berprestasi (tinggi), yaitu kemampuan dan usaha yang merupakan variabel-variabel yang saling menunjang untuk mencapai keberhasilan. Namun, bila dibandingkan dengan atribusi instrinsik dari Wainer, motivasi berprestasi tinggi setidak-tidaknya ada tiga indikator, yaitu kemampuan, usaha, suasana hati (kesehatan).

Berdasarkan uraian di atas, hakikat motivasi berprestasi dalam penelitian ini adalah rangsangan-rangsangan atau daya dorong yang ada dalam diri siswa yang mendasari siswa untuk belajar dan berupaya mencapai prestasi belajar yang diharap- 
kan dengan ciri-ciri di antaranya (1) berkemampuan di atas rata-rata, (2) berupaya keras untuk sukses, (3) berupaya meraih hasil belajar yang tinggi, (4) percaya akan kemampuannya, (5) cenderung bekerja sendiri, (6) cenderung berkelompok dengan teman yang pintar, (7) suka/gemar belajar walaupun sakit, (8) menyelesaikan tugas demi masa depan. (9) tujuan belajar untuk kepuasan diri, (10) cenderung memilih soal yang moderat tingkat kesulitannya, dan (11) cenderung menyelesaikan tugas sendiri.

Berdasarkan konsepsi belajar mandiri dan motivasi berprestasi (dalam belajar) dari berbagai para akhli sebagaimana diuraikan di atas, keberhasilan belajar pada SMP Terbuka termasuk hasil belajar PAI, akan mempunyai koralasi yang signifikan antara kedua variabel tersebut. Pemikiran ini didasari oleh telah banyak penelitianpenelitian yang dilakukan, bahwa ada hubungan yang cukup signifikan antara motivasi berprestasi dan cara belajar seperti belajar mandiri dengan prestasi belajar siswa, termasuk belajar Pendidikan Agama Islam (PAI).

Prestasi belajar dapat diartikan sebagai hasil yang dicapai oleh individu setelah mengalami suatu proses belajar dalam jangka waktu tertentu. Prestasi belajar juga diartikan sebagai kemampuan maksimal yang dicapai seseorang dalam suatu usaha yang menghasilkan pengetahuan atau nilai-nilai kecakapan. Lebih lanjut, prestasi belajar dapat juga disebut kecakapan aktual (actual ability) yang diperoleh seseorang setelah belajar, suatu kecakapan potensial (potensial ability) yaitu kemampuan dasar yang berupa disposisi yang dimiliki oleh individu untuk mencapai prestasi. ${ }^{17} \mathrm{Keca}-$ kapan aktual dan kecakapan potensial ini dapat dimasukkan ke dalam suatu istilah yang lebih umum yaitu kemampuan (ability). Prestasi belajar dapat ditinjau dari dua perspektif; (1) prestasi atau kemampuan kinerja dalam melakukan tugas tertentu; (2) segala kemajuan yang dicapai di sekolah. ${ }^{18}$ Pertama, prestasi belajar merujuk pada usaha maksimal yang dicapai oleh seseorang setelah melaksanakan usaha-usaha belajar. Kedua, merujuk pada hasil yang dicapai oleh seseorang dalam usaha belajar sebagaimana yang dinyatakan dalam raport atau Surat Tanda Tamat Belajar (STTB).

Prestasi belajar adalah suatu bukti keberhasilan belajar atau kemampuan seseorang siswa dalam melakukan kegiatan belajarnya sesuai dengan bobot yang dicapainya. Dengan kata lain, prestasi belajar adalah kesempurnaan yang dicapai seseorang dalam berpikir, merasa dan berbuat. ${ }^{19}$ Prestasi belajar dapat diukur melalui tes yang sering dikenal dengan tes prestasi belajar atau ujian akhir semester atau ujian akhir kenaikan kelas. Tes prestasi belajar bertujuan mengungkap kemampuan seseorang dalam belajar. Tes prestasi belajar berupa tes yang disusun secara terencana untuk mengungkap performasi maksimal subyek dalam menguasai bahan-bahan atau materi yang telah diajarkan. ${ }^{20}$ Bahan atau materi pembelajaran pada sekolah-sekolah formal seperti SMP Terbuka bersumber dari kurikulum yang berlaku. Pada SMP Terbuka materi pembelajaran dikembangkan dalam bentuk media cetak berupa modul, sebagai bahan belajar mandiri. Semua mata pelajaran dan pokok bahasan yang ada dalam kurikulum, termasuk mata pelajaran Pendidikan Agama Islam (PAI), dikembang dan dibuatkan modulnya, agar siswa dapat belajar mandiri kapan saja, di mana saja sesuai dengan kapasistas yang ada pada setiap siswa. 
Pendidikan dalam Islam lebih banyak dikenal dengan menggunakan istilah altarbiyah, al-ta' lim, al-ta'dib dan al-riyadah. Pendidikan Islam adalah pendidikan manusia seutuhnya, akal dan hatinya, rohani dan jasmaninya, akhlak dan keterampilannya. Karena pendidikan Islam menyiapkan manusia untuk hidup, baik dalam keadaan aman maupun perang, dan menyiapkan untuk menghadapi masyarakat dengan segala kebaikan dan kejahatannya, manis dan pahitnya. ${ }^{21}$

Pendidikan Agama Islam juga dipahami sebagai usaha sadar untuk menyiapkan siswa agar memahami ajaran Islam (knowing), terampil melakukan ajaran Islam (doing), dan melakukan ajaran Islam dalam kehidupan sehari-hari (being).22 Lebih jauh dikatakan bahwa pendidikan agama islam harus dilakukan secara terpadu baik keterpaduan tujuan dan keterpaduan materi maupun keterpaduan proses. Keterpaduan tujuan berarti pencapaian tujuan pendidikan merupakan tanggung jawab semua pemangku kepentingan (stakeholders) pendidikan, yaitu pemerintah, kepala sekolah, guru, orang tua siswa, dan masyarakat. Keterpaduan materi ialah keterpaduan isi kurikulum yang digunakan atau materi pelajaran. Semua materi pelajaran yang dipelajari siswa hendaknya saling memiliki keterkaitan antara satu mata pelajaran dengan mata pelajaran yang lainnya. Pengikat keterpaduan tersebut adalah tujuan pendidikan keimanan dan ketakwaan. Jadi selain tujuan mata pelajaran itu sendiri, hendaknya semua bahan ajar mengarah kepada terbentuknya manusia beriman dan bertakwa. Keterpaduan proses, berarti para pendidik hendaknya menyadari bahwa semua kegiatan pendidikan sekurang-kurangnya tidak berlawanan dengan tujuan pendidikan keimanan dan ketakwaan, bahkan dikehendaki semua kegiatan pendidikan membantu tercapainya siswa yang beriman dan bertakwa. Penerapan model belajar mandiri, siswa akan terbiasa berusaha menghadapi tugas-tugas mata pelajaran termasuk pendidikan agama islam yang harus diselesaikanya.

Gagne dan Briggs ${ }^{23}$ membagi hasil belajar menjadi lima kategori kapabilitas yaitu (1) keterampilan intelektual (intellectual skills), (2) strategi kognitif (cognitive strategies), (3) informasi verbal (verbal information), (4) keterampilan motorik (motor skills), dan (5) sikap (attitudes). Keterampilan intelektual adalah kecakapan yang berkenaan dengan pengetahuan prosedural, mulai dari kemampuan membedakan, konsep konkret, konsep definisi, serta kaidah yang lebih tinggi; kaidah yang mengandung banyak langkah disebut prosedur. ${ }^{24}$

Sementara itu Bloom dan kawan-kawannya, ${ }^{25}$ serta Degeng, ${ }^{26}$ mengklasifikasikan hasil belajar menjadi tiga domain atau ranah, yaitu ranah kognitif, psikomotor, dan sikap. Ranah kognitif menaruh perhatian pada pengembangan kapabilitas dan keterampilan intelektual; ranah psikomotor berkaitan dengan kegiatan-kegiatan manipulatif atau keterampilan motorik; dan ranah sikap berkaitan dengan pengembangan perasaan, sikap, nilai, dan emosi.

Dari uraian di atas dapat disimpulkan bahwa hasil belajar Pendidikan Agama Islam (PAI) siswa SMP Terbuka adalah nilai atau skor yang menggambarkan seberapa banyak siswa menguasai atau mencapai tujuan-tujuan pembelajaran (umum dan khusus) yang telah ditetapkan dalam kurikulum yang berlaku. Dengan kata lain, se- 
berapa banyak materi-materi pembelajaran yang telah ditetapkan dalam kurikulum telah dikuasai oleh siswa. Adapun prestasi hasil belajar PAI siswa SMP Terbuka yang dimaksud dalam penelitian ini adalah nilai diperoleh berdasarkan tes yang dibuat oleh team penyusun dari Majelis Guru Mata Pelajaran (MGMP) yang telah ditetapkan dan ditunjuk oleh Kepala Suku Dinas Pendidikan Wilayah.

Berdasarkan uraian di atas, maka dapat dirumuskan masalah penelitian sebagai berikut:

1. Apakah ada hubungan positif antara belajar mandiri dengan hasil belajar Pendidikan Agama Islam siswa SMP Terbuka?

2. Apakah ada hubungan positif antara motivasi berprestasi dengan hasil belajar Pendidikan Agama Islam siswa SMP Terbuka?

3. Apakah ada hubungan positif antara belajar mandiri dan motivasi berprestasi dengan hasil belajar Pendididkan Agama Islam siswa SMP Terbuka?

\section{METODE}

Penelitian ini menggunakan metode survei dengan pendekatan statistik deskriptif untuk mendeskripsi hal-hal yang berkaitan dengan motivasi berprestasi, belajar mandiri dan prestasi belajar Pendidikan Agama Islam serta menggunakan pendekatan inferensial untuk melihat hubungan motivasi berprestasi dengan prestasi belajar Pendidikan Agama Islam, hubungan belajar mandiri dengan prestasi hasil belajar Pendidikan Agama Islam, dan hubungan motivasi berprestasi dan belajar mandiri secara bersama-sama dengan prestasi hasil belajar Pendidikan Agama Islam.

Penelitian ini dilaksanakan di SMP Terbuka 2 Tanjung Periuk, yang berinduk pada SMP Negeri 55 Tanjung Periuk Jakarta Utara, selama 2 bulan sejak bulan Mei 2010 sampai dengan bulan Juni 2010.

Populasi penelitian adalah semua siswa SMP Terbuka kelasa VII, VIII, dan Kelas IX. dengan sampel penelitian yang diambil dengan purposif acak sederhana sejumlah 30 siswa SMP Terbuka kelas VII. Pengambilan sampel kelas VII dilakukan, karena kelas VIII tidak diijinkan, dan VI baru berpengalaman dalam belajar mandiri selama 10 bulan.

Instrumen yang digunakan untuk mengumpulkan data penelitian ini dalam bentuk tes dan kuesioner, meliputi kuesioner motivasi berprestasi dan belajar mandiri serta tes prestasi belajar akhir semester dua Pendidikan Agama Islam. Sebelum digunakan untuk pengumpulan data, instrumen penelitian terlebih dahulu dilakukan uji validitas dan reliabilitas. Instrumen kuesioner belajar mandiri dan motivasi berprestasi, uji validitas dilakukan dengan Product Moment Validity, sedangkan untuk uji reliabilitas menggunakan Grounbach Alpha. Sementara itu instrumen tes prestasi belajar Pendidikan Agama Islam tidak dilakukan uji validitas dan reliabilitas, dengan alasan item tesnya dianggap telah valid karena disusun oleh team yang dibentuk oleh Kepala Suku Dinas Pendidikan. Instrumen tes yang dikembangkan oleh team tersebut digunakan untuk ujian akhir semester bagi kelas VII SMP seluruh wilayan Jakarta Utara. Diasumsikan sebelum digunakan instrumen tes tersebut telah diujicobakan secara empirik, sebelum digandakan untuk digunakan dalam ujian akhir semester. 
Analisis data dilakukan dengan menggunakan teknik analisis korelasi regresi bivariat dan multiple regresi dengan menggunakan program SPSS versi 18 .

\section{HASIL DAN PEMBAHASAN}

\section{Hasil}

Hasil deskripsi data nilai prestasi hasil belajar Pendidikan Agama Islam menunjukkan $40 \%$ siswa masuk pada kategori kelompok prestasi rendah atau di bawah skor rata-rata, 23,33 \% siswa masuk pada kategori kelompok prestasi rata-rata, dan 36,67\% siswa masuk pada kategori kelompok prestasi tinggi atau di atas rata-rata. Hal ini menunjukkan skor prestasi hasil belajar Pendidikan Agama Islam yang paling banyak dicapai berada pada kisaran nilai 63-74, yaitu dengan frekuensi absolut 18 responden, artinya prestasi hasil belajar Pendidikan Agama Islam siswa cukup tinggi. Hal ini ditandai dengan rasio antara kategori rendah dan kategori rata-rata ditambah di atas rata-rata (40\%:60\%). Untuk lebih jelasnya lihat tabel 1 berikut.

Tabel 1.

Distribusi Frekuensi Skor Ujian Akhir Semester PAI

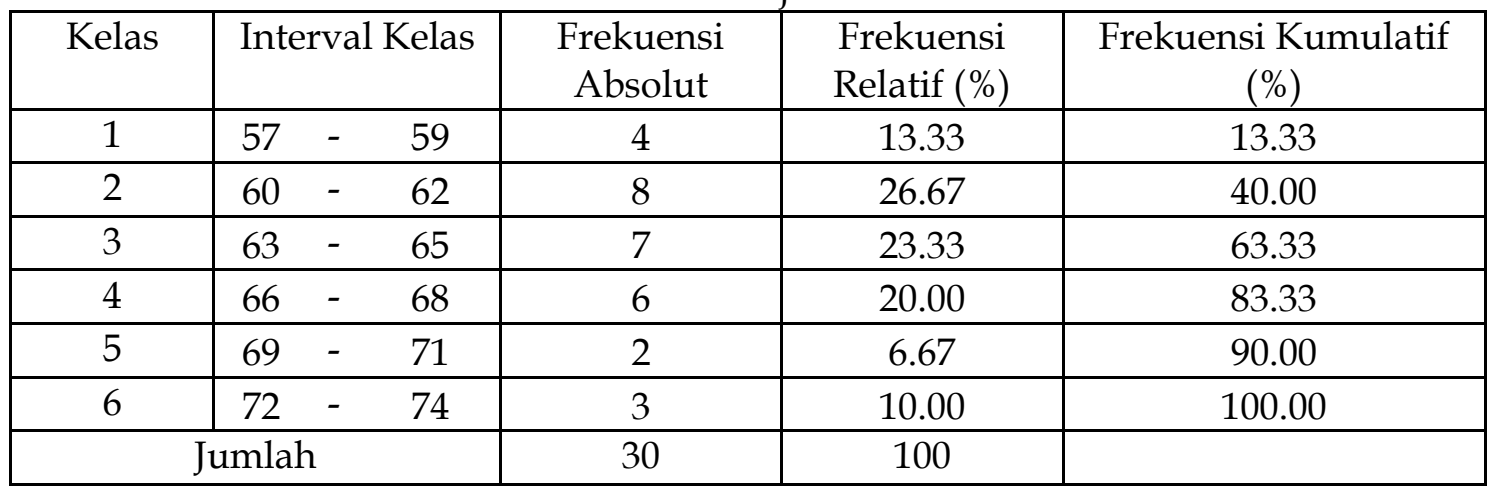

Berdasarkan data Belajar mandiri menunjukkan bahwa 46,67\% siswa masuk pada kategori kelompok rendah atau di bawah skor rata-rata, 13,33\% siswa masuk pada kategori kelompok rata-rata, dan 40\% siswa masuk pada kategori kelompok tinggi atau di atas rata-rata. Hal ini menunjukkan nilai skor belajar mandiri yang paling banyak dicapai berada pada kisaran nilai skor 68-79, yaitu dengan frekuensi absolut 16 responden, artinya program pembelajaran belajar mandiri cukup baik. Hal ini ditandai dengan rasio antara kategori rendah dan kategori rata-rata ditambah dengan kategori di atas rata-rata $(46,67 \%: 53,33 \%)$. Untuk lebih jelasnya lihat tabel 2 berikut.

Tabel 2.

Distribusi Frekuensi Skor Belajar Mandiri

\begin{tabular}{|c|c|c|c|c|}
\hline Kelas & Interval Kelas & $\begin{array}{c}\text { Frekuensi } \\
\text { Absolut }\end{array}$ & $\begin{array}{c}\text { Frekuensi } \\
\text { Relatif }(\%)\end{array}$ & $\begin{array}{c}\text { Frekuensi Kumulatif } \\
(\%)\end{array}$ \\
\hline 1 & $56-59$ & 3 & 10.00 & 10.00 \\
\hline 2 & $60-63$ & 6 & 20.00 & 30.00 \\
\hline 3 & $64-67$ & 5 & 16.67 & 46.67 \\
\hline
\end{tabular}




\begin{tabular}{|c|c|c|c|c|}
\hline 4 & $68-71$ & 4 & 13.33 & 60.00 \\
\hline 5 & $72-75$ & 8 & 26.67 & 86.67 \\
\hline 6 & $76-79$ & 4 & 13.33 & 100.00 \\
\hline \multicolumn{2}{|c|}{ Jumlah } & 30 & 100 & \\
\hline
\end{tabular}

Sementara itu skor motivasi berprestasi menunjukkan $40 \%$ siswa masuk pada kategori kelompok rendah atau di bawah skor rata-rata, 26,67\% siswa masuk pada kategori kelompok rata-rata, dan $43,33 \%$ siswa masuk pada kategori kelompok tinggi atau di atas rata-rata. Namun nilai skor motivasi berprestasi yang paling banyak dicapai berada pada kisaran nilai skor 145-163, yaitu dengan frekuensi absolut 21, artinya motivasi prestasi siswa cukup tinggi. Hal ini ditandai dengan rasio antara kategori motivasi berprestasi rendah dan kategori motivasi berprestasi rata-rata ditambah dengan motivasi berprestasi di atas rata-rata (40\%:60\%).

Tabel 3.

Distribusi Frekuensi Skor Motivasi Berbrestasi

\begin{tabular}{|c|c|c|c|c|}
\hline Kelas & Interval Kelas & $\begin{array}{c}\text { Frekuensi } \\
\text { Absolut }\end{array}$ & $\begin{array}{c}\text { Frekuensi } \\
\text { Relatif }(\%)\end{array}$ & $\begin{array}{c}\text { Frekuensi Kumulatif } \\
(\%)\end{array}$ \\
\hline 1 & $137-140$ & 4 & 13.33 & 13.33 \\
\hline 2 & $141-144$ & 8 & 26.67 & 40.00 \\
\hline 3 & $145-148$ & 5 & 16.67 & 56.67 \\
\hline 4 & $149-152$ & 4 & 13.33 & 70.00 \\
\hline 5 & $153-156$ & 5 & 16.67 & 86.67 \\
\hline 6 & $157-160$ & 4 & 13.33 & 100.00 \\
\hline
\end{tabular}

\section{Hubungan Antara Belajar Mandiri dengan Hasil Belajar Pendidikan Agama Islam}

Uji hubungan belajar mandiri dengan prestasi hasil belajar Pendidikan Agama Islam menghasilkan persamaan regresi $\hat{Y}=32,934+0,457 X_{1}$, dan dapat digambarkan sebagai berikut:

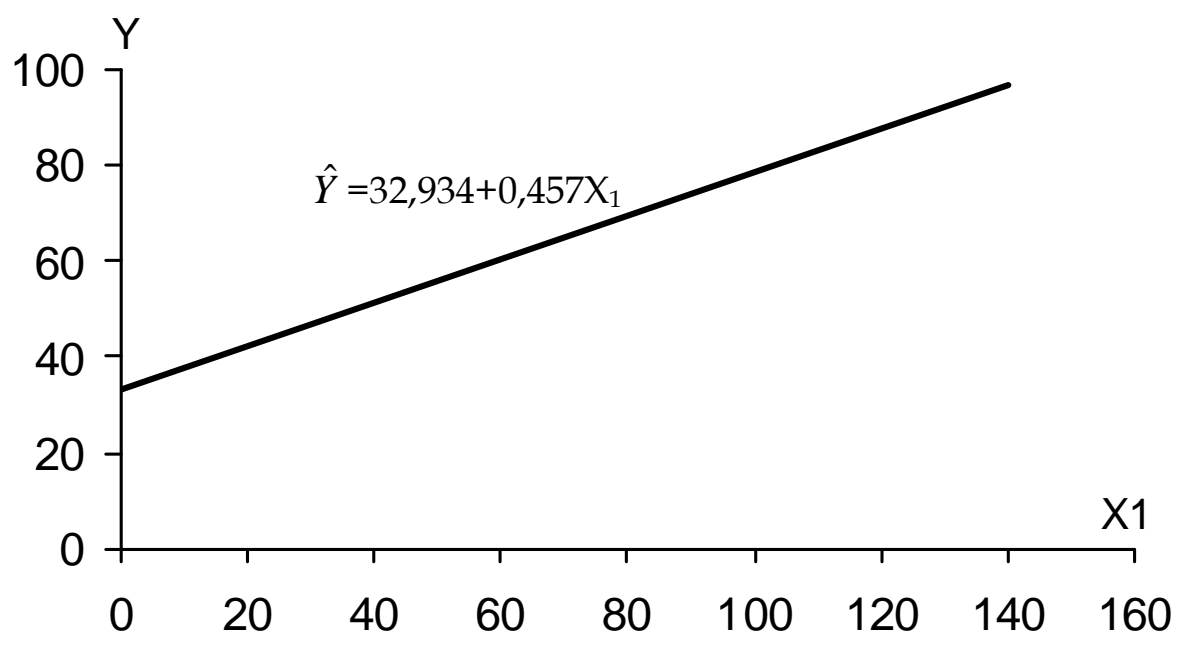

Gambar 1. Regresi Linear Sederhana $\hat{Y}=32,934+0,457 X_{1}$ 
Berdasarkan hasil uji, nilai $F_{\text {hitung }}$ uji signifikansi persamaan regresi sebesar 24,775 pada taraf signifikansi 0,05. Nilai $F_{\text {hitung }}$ untuk linearitas diperoleh sebesar 1,704 $<\mathrm{F}_{\text {tabel }} 3,44$. Untuk jelasnya dapat dilihat pada tabel berikut:

Tabel 4. Tabel Analisis Varians (ANAVA) Untuk Uji Signifikansi dan Linieritas Regresi $\hat{Y}=32,934+0,457 X_{1}$

\begin{tabular}{|l|c|c|c|c|c|c|}
\hline Sumber Variasi & $\mathrm{dk}$ & $\mathrm{JK}$ & $\mathrm{RJK}$ & $\mathrm{F}_{\text {hitung }}$ & \multicolumn{2}{|c|}{$\mathrm{F}_{\text {tabel }}$} \\
\cline { 6 - 8 } & & & & & $\alpha 0,05$ & $\alpha 0,01$ \\
\hline Total Reduksi & 29 & 580,167 & & & & \\
\hline Regresi (b|a) & 1 & 272,355 & 272,355 & $24,775^{* *}$ & 4,20 & 7,64 \\
Sisa & 28 & 307,811 & 10,993 & & & \\
\hline Tuna Cocok & 18 & 232,145 & 12,897 & $1,704^{\mathrm{ns}}$ & 2,80 & 4,49 \\
Galat & 10 & 75,667 & 7,567 & & & \\
\hline
\end{tabular}

$\mathrm{Jk} \quad=$ jumlah kuadrat

$\mathrm{dk}=$ derajat kebebasan

Rjk = rata-rata Jumlah kuadrat

** $\quad=$ regresi sangat signifikan $\left(\mathrm{F}_{\mathrm{h}}=24,775>\mathrm{F}_{\mathrm{t}}=7,64\right)$

ns $\quad=$ regresi linear $\left(\mathrm{F}_{\mathrm{h}}=1,704<\mathrm{F}_{\mathrm{t}}=2,80\right)$

Besar koefisien korelasi sebesar 0,685, sedangkan besar koefisien determinasi belajar mandiri terhadap prestasi hasil belajar Pendidikan Agama Islam adalah sebesar 0,469 atau 46,9\%, sedangkan sisanya 53,1\% dipengaruhi oleh variabel lain.

\section{Hubungan Antara Motivasi Berprestasi dengan Hasil Belajar Pendidikan Agama Islam}

Uji hubungan motivasi berprestasi dengan hasil belajar Pendidikan Agama Islam memperoleh persamaan regresi $\hat{Y}=1,333+0,426 X_{2}$, secara visual digambarkan sebagai berikut:

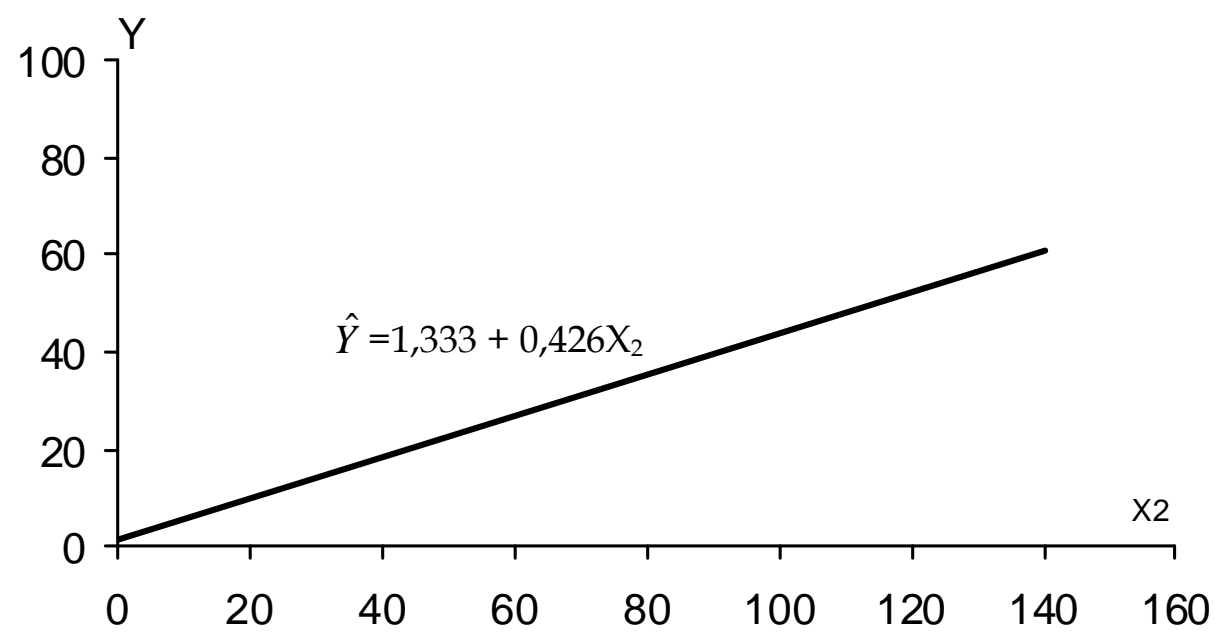

Gambar 2. Regresi Linear Sederhana $\hat{Y}=1,333+0,426 X_{2}$ 
Hasil uji signifikansi persamaan regresi dan linearitas menunjukkan bahwa nilai $F_{\text {hitung }}$ diperoleh sebesar 18,537, sedangkan nilai $F_{\text {tabel }}$ dengan $\mathrm{dk}$ pembilang 1 dan dk penyebut 28 pada taraf signifikasi 0,01 sebesar 7,64 . Ternyata nilai $F_{\text {hitung }}$ lebih besar dari nilai $\mathrm{F}_{\text {tabel. }}$ Maka dapat disimpulkan bahwa koefisien arah regresi $\mathrm{Y}$ atas $\mathrm{X}_{2}$ adalah "sangat signifikan" pada taraf signifikansi 0,01 . Nilai F linearitas hasil perhitungan diperoleh sebesar 0,587, sedangkan nilai $\mathrm{F}_{\text {tabel }}$ dengan $\mathrm{dk}$ pembilang $17 \mathrm{dan} \mathrm{dk}$ penyebut 11 pada taraf signifikansi 0,05 sebesar 2,69. Ternyata nilai $F_{\text {hitung }}$ lebih kecil dari nilai $F_{\text {tabel. }}$ Maka dapat disimpulkan bahwa bentuk regresi $\mathrm{Y}$ atas $\mathrm{X}_{2}$ adalah "linear", seperti yang disajikan pada tabel berikut:

Tabel 5. Tabel Analisis Varians (ANAVA) Untuk Uji Signifikansi dan Linieritas Regresi $\hat{Y}=1,333+0,426 X_{2}$

\begin{tabular}{|l|c|c|c|c|c|c|}
\hline Sumber Variasi & $\mathrm{dk}$ & $\mathrm{JK}$ & $\mathrm{RJK}$ & $\mathrm{F}_{\text {hitung }}$ & \multicolumn{2}{|c|}{$\mathrm{F}_{\text {tabel }}$} \\
\cline { 5 - 7 } & & & & & $\alpha 0,05$ & $\alpha 0,01$ \\
\hline Total Reduksi & 29 & 580,167 & & & & \\
\hline Regresi (b|a) & 1 & 231,100 & 231,100 & $18,537^{* *}$ & 4,20 & 7,64 \\
Sisa & 28 & 349,066 & 12,467 & & & \\
\hline Tuna Cocok & 17 & 166,769 & 9,769 & $0,587 \mathrm{~ns}$ & 2,69 & 4,19 \\
Galat & 11 & 183,000 & 16,636 & & & \\
\hline
\end{tabular}

** $\quad=$ regresi sangat signifikan $\left(\mathrm{F}_{\mathrm{h}}=18,537>\mathrm{F}_{\mathrm{t}}=7,64\right)$

ns $\quad=$ regresi linear $\left(F_{h}=0,587<F_{t}=2,69\right)$.

Koefisien korelasi sebesar 0,631, sedangkan besar koefisien determinasi motivasi berprestasi terhadap prestasi hasil belajar Pendidikan Agama Islam adalah 0,398 atau $41,9 \%$, sisanya $58,1 \%$ dipengaruhi oleh variabel lain.

\section{Hubungan Antara Belajar Mandiri dan Motivasi Berprestasi dengan Hasil Belajar Pendidikan Agama Islam}

Uji hubungan belajar mandiri dan motivasi berprestasi secara bersama-sama dengan hasil belajar Pendidikan Agama Islam memperoleh nilai $F_{\text {hitung }}$ uji signifikansi persamaan regresi sebesar 24,775 pada taraf signifikansi 0,05 seperti yang disajikan pada tabel sebagai berikut:

Tabel 6. Analisis Varians (ANAVA) untuk Regresi Ganda

$$
\hat{\mathrm{Y}}=8,974+0,318 \mathrm{X}_{1}+0,227 \mathrm{X}_{2}
$$

\begin{tabular}{|l|c|c|c|c|c|c|}
\hline \multirow{2}{*}{ Sumber Varians } & \multirow{2}{*}{$\mathrm{dk}$} & $\mathrm{JK}$ & $\mathrm{RJK}$ & $\mathrm{F}_{\mathrm{h}}$ & \multicolumn{2}{|c|}{$\mathrm{F}_{\mathrm{t}}$} \\
\cline { 6 - 8 } & & & & & 0,05 & 0,01 \\
\hline Total direduksi & 29 & 580,167 & & & & \\
\hline Regresi & 2 & 312,735 & 156,367 & $15,787^{*}$ & 4,74 & 9,55 \\
Sisa & 27 & 267,432 & 9,905 & & & \\
\hline
\end{tabular}

** regresi sangat signifikan pada $\alpha=0,01$

Dan menghasilkan koefisien korelasi ganda sebesar 0,734. Dapat diartikan bahwa hubungan motivasi berprestasi dan belajar mandiri memiliki hubungan positif dan signifikan dengan hasil belajar Pendidikan Agama Islam. Selain itu diketahui pu- 
la bahwa motivasi berprestasi dan belajar mandiri secara bersama-sama memberikan sumbangan sebesar 53,9\% terhadap hasil belajar Pendidikan Agama Islam. Dengan demikian kontribusi variabel motivasi berprestasi dan belajar mandiri secara bersamasama terhadap prestasi hasil belajar Pendidikan Agama Islam tergolong sangat berarti.

\section{Pembahasan}

Perbedaan hasil tes prestasi belajar Pendidikan Agama Islam menunjukkan bahwa item tews yang disusun oleh team mampu membedakan kapasitas siswa yang mempunyai motivasi berprestasi (dalam belajar) dan kemandirian dalam belajar PAI. Kalau tes yang diberikan oleh guru tidak melalui pelaksanaan uji coba untuk mengetahui tingkat daya beda dan kesukaran soal memungkinkan tidak memberikan gambaran perbedaan yang signifikan secara empiris.

Hasil nilai skor belajar mandiri yang diperoleh berdasarkan nilai rata-rata empirik menunjukkan bahwa proses belajar siswa SMP Terbuka dengan program belajar mandiri sangat mendukung prestasi belajar Pendidikan Agama Islam karena sebagian besar siswa memilih berusaha untuk menyelesaikan tugas-tugas dengan belajar mandiri, baik belajar sendiri maupun belajar dalam kelompok, terutama tugas-tugas serta tes akhir modul yang telah tersedia dalam modul. Termasuk pula tugas-tugas rumah yang diberikan oleh guru dari soal-soal tes siswa kelas reguler sebagai induk SMP Terbuka untuk dikerjakan langsung di kelas, dan mereka berusaha menjawab dengan sungguh-sungguh dan hasilnya $76 \%$ dari tugas-tugas dan tes akhir modul PAI dapat dijawab dengan benar. Dengan hasil belajar PAI yang diperoleh melalui belajar mandiri ini, berarti seluruh siswa kelas VII SMP Terbuka telah tuntas menyelesaikan modul-modul PAI untuk kelas VII dan mereka telah melampaui batas angka standar ketuntasan yang telah ditentuka sebesar 75\%. Dalam sistem belajar mandiri pada SMP Terbuka khususnya materi pendidikan Agama Islam, Pendidikan Keterampilan, dan Muatan lokal. Peranan orang tua dan tokoh masyarakat sangat diperlukan. Dari hasil hubungan belajar mandiri dengan hasil belajar Pendidikan Agama Islam dalam penelitian ini setidak-tidaknya sumbangan peran tokoh agama dan orang tua siswa telah memberikan kontribusi yang diasumsikan cukup signifikan. Belajar mandiri siswa tidak akan berjalan dengan baik dan sukses bila tidak ditopang oleh orang tua dan tokoh masyarakat. Lebih-lebih masyarakat di sekitar penelitian ini pada umumnya atau sebagian besar beragama Islam. Orang tua siswa mengharapkan anaknya dapat manjaga dan menguasai konsep Pendidikan Agama Islam sesuai dengan pandangannya. Dilihat dari sudut harapan masyarakat dan orang tua, terhadap Pendidikan Agama Islam di sekolah tercatat secara sederhana yaitu: anaknya menguasai dasar-dasar agama, termasuk kemampuan membaca Al-Qur'an dan berdoa, taat beribadah (shalat, zakat), dan berakhlak luhur. ${ }^{27} \mathrm{Hal}$ ini sejalan dengan konsep pendidikan dalam Islam menurut Zakiah Darajat di antaranya, (1) Pendidikan Islam berlanjut sepanjang hayat, mulai dari manusia sebagai janin dalam kandungan ibunya sampai kepada berakhirnya hidup di dunia ini, dan (2) Maka kurikulum Pendidikan Islam akan menghasilkan manusia yang memperoleh hak di dunia dan hak di akhirat nanti. 
Sementara tujuan Pendidikan dalam Islam secara garis besarnya adalah untuk membina manusia agar menjadi hamba Allah yang shaleh dengan seluruh aspek kehidupannya, perbuatan, pikiran dan perasaannya. ${ }^{28}$

Selain itu hasil penelitian menunjukkan bahwa belajar mandiri mempunyai hubungan positif dengan prestasi belajar Pendidikan Agama Islam dengan sumbangan sebesar 45,9\%. Berarti variabel belajar mandiri secara konsisten berhubungan searah dengan prestasi belajar Pendidikan Agama Islam. Yang berarti makin tinggi kegiatan belajar mandiri siswa makin tinggi pula prestasi belajar Pendidikan Agama Islam yang diperolehnya.

Sementara itu, berdasarkan hasil skor motivasi berprestasi yang diperoleh berdasarkan nilai rata-rata empirik menunjukkan bahwa siswa SMP Terbuka memiliki motivasi berprestasi tinggi untuk mengikuti pembelajaran Pendidikan Agama Islam karena sebagian besar siswa memilih berusaha untuk menyelesaikan tugas-tugas, baik tugas dalam modul maupun soal-soal yang diberikan oleh guru untuk dikerjakan langsung di kelas seperti tes akhir modul, dan mereka berusaha menjawab dengan sungguh-sungguh dan hasilnya $76 \%$ dapat dijawab dengan benar.

Motivasi berprestasi mempunyai hubungan positif dengan prestasi belajar Pendidikan Agama Islam dengan kontribusi atau sumbangan variabel motivasi berprestasi terhadap variabel prestasi belajar Pendidikan Agama Islam sebesar 39,8\%. Berarti motivasi berprestasi memberikan sumbangan yang cukup dan secara konsisten berhubungan searah dengan prestasi belajar Pendidikan Agama Islam. Dengan demikian makin tinggi motivasi berprestasi siswa makin tinggi pula prestasi belajar Pendidikan Agama Islam yang diperolehnya.

Penelitian ini menemukan hubungan positif antara belajar mandiri dan motivasi berprestasi secara bersama-sama dengan prestasi belajar Pendidikan Agama Islam. Dengan kontribusi atau sumbangannya sebesar 53,9\%, sedangkan sisanya sebesar. $46,1 \%$ ditentukan oleh variabel lain yang tidak masuk dalam penelitian ini.

Berdasarkan peringkat besar kekuatan hubungan, di mana kekuatan hubungan antara belajar mandiri dengan hasil belajar Pendidikan Agama Islam, menempati peringkat pertama dan hubungan antara motivasi berprestasi dengan hasil belajar Pendidikan Agama Islam, menempati peringkat kedua. Artinya, kekuatan hubungan antara belajar mandiri dengan hasil belajar Pendidikan Agama Islam lebih kuat dibandingkan kekuatan hubungan motivasi berprestasi dengan prestasi belajar Pendidikan Agama Islam.

\section{SIMPULAN}

Berdasarkan uraian dari hasil penelitian di atas dapat disimpulkan bahwa:

1. Sistem belajar mandiri mempunyai hubungan positif dengan hasil belajar Pendidikan Agama Islam siswa SMP Terbuka, khususnya siswa kelas VII. Dengan kata lain sistem belajar mandiri dapat meningkatkan prestasi belajar Pendidikan Agama Islam. Apabila ingin meningkatkan hasil belajar Pendidikan Agama Islam Siswa SMP Terbuka, maka program belajar mandiri siswa perlu ditingkatkan kua- 
litasnya. Untuk menopang sistem belajar mandiri yang kondusif, pemerintah dan sekolah seyogyanya menyediakan berbagai macam sumber belajar dan media pembelajaran yang dapat dipilih dan dimanfaatkan siswa secara mandiri dalam belajar sendiri maupun kelompok baik di tempat kegiatan belajar (TKB), di SMP Induk maupun di rumah.

2. Motivasi berprestasi mempunyai hubungan positif dengan hasil belajar Pendidikan Agama Islam pada siswa SMP Terbuka. Dengan kata lain motivasi berprestasi dapat meningkatkan prestasi belajar Pendidikan Agama Islam. Apabila ingin meningkatkan hasil belajar Pendidikan Agama Islam pada Siswa SMP Terbuka, khususnya siswa kelas VII, maka motivasi berprestasi dalam belajar siswa perlu ditingkatkan. Untuk itu sistem pembelajaran pada SMP Terbuka perlu diupayakan secara kondisional sehingga memungkinkan terciptanya lingkungan belajar yang memacu peningkatan motivasi berprestasi (dalam belajar) bagi siswa SMP Terbuka. Selain itu sejalan dengan pekembangan Teknologi Informasi dan Komunikasi (TIK) untuk pendidikan, sumber-sumber belajar dan media pembelajaran yang berbasis TIK perlu dikembangkan dan dimanfaatkan secara blended sebagai salah satu upaya peningkatan hasil belajar siswa khususnya PAI dan umumnya mata pelajaran-mata pelajaran lain yang ada dalam kurikulum SMP yang berlaku. Tersedianya sumber-sumber belajar yang dikemas secara menarik dan menyenangkan melalui komunikasi berbasis TIK, tidak hanya meningkatkan motivasi berprestasi (dalam belajar) siswa, namun juga mampu menciptakan lingkungan belajar yang kondusif bagi siswa untuk belajar mandiri.

3. Belajar mandiri dan motivasi berprestasi secara bersama-sama mempunyai hubungan positif dengan hasil belajar Pendidikan Agama Islam pada siswa SMP Terbuka. Berarti hasil belajar Pendidikan Agama Islam siswa SMP Terbuka dapat ditingkatkan melalui upaya peningkatan motivasi berprestasi dan program belajar mandiri yang berkualitas dengan secara sendiri-sendiri maupun secara bersamasama. Dengan kata lain, makin tinggi motivasi berprestasi siswa dan makin baik program belajar mandiri maka makin tinggi hasil belajar Pendidikan Agama Islam siswa SMP Terbuka.

\section{CATATAN AKHIR}

1. Nurdin Ibrahim, 25 tahun SMP Terbuka (dalam Mozaik Teknologi Pendidikan), ed. Dewi SP dan Evelin Siregar, Jakarta, UNJ, 2004. h. 284.

2. Desmond Keegan, The Foundation of Distance Education, Dover Biddles Ltd Buildford and King's Lyon, 1996, h. 59.

3. Michael G. Moore \& Greg Kearsley, Distance Education A Systems View, Belmont: Wadsworth Publishing Company, 1996, h. 24.

4. Nada Dabbagh and Brenda Bannan-Retland, Online Learning, Consep, Strategies, and Application, Colombus Ohio: Pearson Merrill Prentice Hall, 2005, h. 5.

5. Desmond Keegan, Op Cit. h. 70.

6. Nurdin Ibrahim, Perspektif Pendidikan Terbuka Jarak Jauh; Kajian Teoritis dan Aplikasi, Jakarta. Bumi Aksara, 2010, h. 31.

7. Richard M. Steers and Lyman W. Porter, Motivation and Work Behavior, New York: McGrew-Hill Inc., 1991, h. 5. 
8. Jujun S. Suriasumantri, Berfikir Sistem; Konsep, Penerapan, Teknologi dan Strategi Implementasi, Jakarta: Fakultas Pasca Sarjana IKIP Jakarta, tanpa tahun, h. 92.

9. Robert C. Beck, Motivation Theories and Principle, New Jersey: Prentice-Hall, Inc., 1990, h. 19.

10. Ivor K. Davies, Instructional Technique, New York: McGrow-Hill Book Company, 1981, h. 74 .

11. Thomas K. Crowl, Sally Kaminsky, \& David M. Podell, Educational Psychology Windows on Teaching, London: Brown \& Benchmark Publishing, 1997, h. 239-240.

12. Thomas L. Good, and Jere E. Brophy, Educational Psychology A Realistic Ap-proach, New York: Longman, 1990, h. 380-382.

13. Margaret E. Bell Gredler, Learning and Instruction, Alih Bahasa Tri Wibowo BS dan disunting oleh Yusufhadi Miarso, Jakarta: Prenada Group, 2011, h. 482.

14. David C. McClelland dkk., The Achievement Motive, New York: Irvington Publis-hers, 1976, h. 74-75.

15. Robert M. W. Travers, Essential of Learning; The New Cognitive Learniong for Students of Education, USA: Macmillan Publishing Co Inc., 1982, h. 435.

16. Richard M. Steers and Lyman W. Porter, Motivation and Work Behavior, New York: McGrew-Hill Inc., 1991, h. 39-40.

17. Nurkancana, Definisi Prestasi Belajar, h. 1, 2010 (http://matematikamobile.uni.cc/pres-tasibelajar-matematika).

18. Gary D. Phye, A Handbook of Classroom Assessment: Learning, Achievement, and Adjustment, Ames, IA: Academic Press, 1997, h. 5.

19. Ibid. h. 6.

20. Anna Logsdon, Achievement Testing - Testing Achievement in Learning Disability Diagnosis, $\mathrm{h}$. 1, 2010, (http://learningdisabilities.about.com/od/glossar1/p/achievementtest.htm).

21. Yusuf Qardhawi dalam Subhan, http://wonk-educationnetwork.blogspot.com/2007/03/pendidikan-agama-islam.html Pendidikan Agama Islam: Sebagai Transformasi Potensialitas ke Aktualitas, hal. 3, 2010 (http://wonk-educationnetwork.blogspot.com/2007/03/pendi-dikan-agama-islam.html).

22. A. Tafsir, Pendidikan Agama Islam di Sekolah, h. 1, 2010, (http://idb1.wikispaces.com/file/view/jj1001.pdf)

23. Robert M. Gagne, and Lislie J. Briggs, Principle of Instructional Design, New York: Holt Rinchart and Winstone, 1989.

24. Robert M. Gagne, The Conditions of Learning, New York: Holt, Rinehart and Winston, 1989, h. 90.

25. Benjamin S. Bloom dkk., Taxonomy of Education Objectives The Classification of Educational Gools Handbook I: Cognitive Domain, New York: Longman Inc., 1956.

26. I Nyoman S. Degeng, Ilmu Pengajaran; Taksonomi Variabel, Jakarta: Depdikbud Ditjen Dikti,. 1989, h. 176-177.

27. Husni Rahim, Arah Baru Pendidikan Islam di Indonesia, Jakarta: Logos Wacana Ilmu, 2001, h. 39.

28. Zakiah Darajat, Pendidikan Islam dalam Keluarga dan Sekolah, Bandung: PT. Remaja Rosdakarya, 1994, h. 35.

\section{DAFTAR PUSTAKA}

Beck, Robert C,. Motivation: Theories and Principles, New Jersey: Prentice-Hall, Inc. 1990.

Bloom, Benjamin S., dkk., Taxonomy of Education Objectives The Classification of Educational Gools Handbook I: Cognitive Domain, New York: Longman Inc. 1956.

Crowl, Thomas K., Sally Kaminsky, \& David M. Podell, Educational Psychology Windows on Teaching, London: Brown \& Benchmark Publishing, 1997. 
Dabbagh, Nada and Brenda Bannan-Retland, Online Learning, Consep, Strategies, and Application, Colombus Ohio: Pearson Merrill Prentice

Darajat, Zakiah, Pendidikan Islam dalam Keluarga dan Sekolah, Bandung: PT. Remaja Rosdakarya, 1994.

Davies, Ivor K., Instructional Technique, New York: McGrow-Hill Book Company, 1981.

Degeng, I. Nyoman S., Ilmu Pengajaran; Taksonomi Variabel, Jakarta: Depdikbud Ditjen Dikti,. 1989.

Gagne, Robert M., and Lislie J. Briggs, Principle of Instructional Design, New York: Holt Rinchart and Winstone, 1989.

Gagne, Robert M., The Conditions of Learning, New York: Holt, Rinehart and Winston, 1989.

Good, Thomas L. and Jere E. Brophy, Educational Psychology A Realistic Approach, New York: Longman, 1990.

Gredler, Margaret E. Bell, Learning and Instruction, Alih Bahasa Tri Wibowo BS dan disunting oleh Yusufhadi Miarso, Jakarta: Prenada Group, 2011.

Ibrahim, Nurdin, 25 tahun SMP Terbuka (dalam Mozaik Teknologi Pendidikan), ed. Dewi SP dan Evelin Siregar, Jakarta, UNJ, 2004.

Ibrahim, Nurdin, Perspektif Pendidikan Terbuka Jarak Jauh; Kajian Teoritis dan Aplikasi, Jakarta: Bumi Aksara, 2010.

Keegan, Desmond, The Foundation of Distance Education, Dover Biddles Ltd Buildford and King's Lyon, 1996.

Logsdon, Anna, 2010, Achievement Testing in Learning Disability Diagnosis, 2010, (http://learningdisabilities.about.com/od/glossar1/p/achievementtest.htm).

McClelland, David C., dkk. The Achievement Motive, New York: Irvington Publishers, 1976.

Moore, Michael G., \& Kearsley, Greg, Distance Education A Systems View, Belmont: Wadsworth Publishing Company, 1996.

Nurkancana, Definisi Prestasi Belajar, h. 1, 2010 (http://matematikamobile.uni.cc/prestasibelajar-matematika).

Phye, Gary D., A Handbook of Classroom Assessment: Learning, Achievement, and Adjustment, Ames, IA: Academic Press, 1997.

Qardhawi, Yusuf, dalam Subhan, http://wonk-educationnetwork.blogspot.com/2007/03/pendidikan-agama-islam.html Pendidikan Agama Islam: Sebagai Transformasi Potensialitas ke Aktualitas, hal. 3, 2010 (http://wonk-educationnetwork.blogspot.com/2007/03/ pendi-dikan-agama-islam.html).

Rahim, Husni, Arah Baru Pendidikan Islam di Indonesia, Jakarta: Logos Wacana Ilmu, 2001.

Steers, Richard M. and Lyman W. Porter, Motivation and Work Behavior, New York: Mc-GrewHill Inc., 1991.

Suriasumantri, Jujun S., Berpikir Sistem; Konsep, Penerapan, Teknologi dan Strategi Implementasi, Jakarta: Fakultas Pasca Sarjana IKIP Jakarta; tanpa tahun.

Tafsir, Ahmad, Pendidikan Agama Islam di Sekolah, 2010, (http://idb1.wikispaces.com/file/view-/jj1001.pdf)

Travers, Robert M. W., Essential of Learning; The New Cognitive Learniong for Students of Education, USA: Macmillan Publishing Co. Inc., 1982. 